\title{
Polish society towards the implementation of the circular economy and the change of municipal waste management - ecological, economic and social aspect
}

Assoc. Prof. Dr Eng. Joanna Zarębska,

University of Zielona Góra, Faculty of Economics and Management, Poland,

ORCID: 0000-0002-1655-3086.

MSc Eng., Andrzej Zarębski, Maritime University of Szczecin, Faculty of Mechatronics and Electrical Engineering, Poland,

ORCID: 0000-0003-1702-5442.

Assoc. Prof. Dr Eng. Anna Lewandowska, Poznań University of Economics and Business, Department of Standardized Management Systems, Poland, ORCID: 0000-0003-1508-879X.

\section{Introduction}

There is only one earth, but people act as if its resources were endless and all pollution disappeared by itself. Despite numerous conferences and declarations of circular economy (CE) or sustainable development (SD), the goals of these concepts are not implemented or are implemented very slowly (Corona et al. 2019; Figger et al. 2018; Korhonen et al. 2018; Matschewsky et al. 2019). An example may be the member states of the European Union, the specificity of which means that in each of them the CE concept is implemented at a different level (Eionet Report 2019; Ellen MacArthur Foundation 2016).

The European Union (EU) pursues a goal whose main aim is not only sustainable development, but the creation of a recycling society in the broad sense (2008/98/EC p. 3-12; (EU)2018/851 pp. 109-140), through effective and sustainable management of the available resources meeting human needs and by avoiding waste generation. The new plans of the European Commission continue 
to include: improving products and changing consumption patterns, improving production efficiency, transforming waste into resources, supporting research and innovation in the pursuit of a resource efficient society (COM (2011) 571). COM (2014) 398 Towards a circular economy: A zero waste program for Europe recommends a transition to a waste-free economy, following the established waste hierarchy, where waste minimization is a priority and landfilling is a last resort (COM (2014) 398).

While production and service companies are under constant control (at least theoretically), they must account for waste, transfer them for management to specialized companies, implement environmental "good practices" in the scope of $\mathrm{CE}$, the consumer/ resident is a producer of pads without much control. Sometimes it is enough to analyze and compare Reports of the European Environment Agency (EEA 2021), databases of the Central Statistical Office (Polish: GUS 2020), Internet resources (Pożary odpadów... 2021) or media reports (radio, television).

As an EU member state, Poland implements the SD and CE principles. However, the analysis of the national Central Statistical Office documents and the authors' research and the literature review in this area are not optimistic (Zarębska et al. 2018; GUS 2020; Zarębska 2019; Zarębska and Lewicka 2020, pp. 50-57). The aim of the article is to indicate the current achievements of Poland in the field of waste management in the direction of circular economy and "zero waste" (especially municipal and packaging waste management) and the barriers that hinder the achievement of the EU targets in this area. Man is a weak link in the $\mathrm{CE}$. The authors' research confirmed this conclusion. It is the people working in industrial and service enterprises, public institutions, i.e. us as consumers, who largely determine how quickly and at what level the recovery and recycling of municipal waste and the implementation of $\mathrm{CE}$ and SD assumptions will be. Research shows that part of the Polish society $(25 \%)$ does not segregate waste "at the source" (i.e. at home) despite the obligation to pay higher fees and disposes of waste incorrectly. Additionally, unexplained arson on landfills, throwing waste to "neighbors", dumping illegal waste into forests are not conducive to the implementation of CE.

\section{Materials and Methods}

In order to indicate the current achievements of Poland in the field of waste management in the direction of $\mathrm{CE}$ a research has been made. In the research secondary and primary data used. Two main sources of secondary information

Polish society towards the implementation of the circular economy and the change of municipal waste management - ecological, economic and social aspect 
applied - the Eurostat database and databases of the Central Statistical Office GUS. The primary information was collected by performing a survey where two following methods were used: PAPI - paper questionnaire (58\% of responses) and CAWI - Computer Aided Web Interview (42\% of responses). The study used the survey method with open and closed questions on 1076 adults representing 16 districts of Poland. This study was conducted in 2015-2016 and described in detail in the habilitation monograph "Packaging waste management in the context of a circular economy - the essence, tools, environmental communication" (Zarębska 2019). The article presents only a few results summarized in the figure 6 in order to illustrate the problem / social barrier for the implementation of $\mathrm{CE}$, which is the lack of $100 \%$ recovery and segregation of municipal waste at consumer homes. The aim of the article is to present the specificity of the Polish market and to present own research showing the degree of consumer preparation for the implementation of CE.

In addition, the authors of the publication made an observation of the market of selected goods in 3 large cities of western and central Poland (Poznan - the capital of the Greater Poland District, Szczecin - the West Pomeranian District and Zielona Góra - the Lubuskie District) and an analysis of the subject literature, reports: Eurostat, Central Statistical Office, EEA - European Environment Agency, Polish Agency for Enterprise Development (in Polish: PARP), which allowed for drawing additional conclusions.

The barriers that prevent the rapid implementation of the principles of sustainable development and circular economy were indicated, especially in the field of proper segregation and recovery of municipal waste (plastic, glass, paper, multi-material packaging, textiles). Examples of good practices in this area of research and pro-ecological behavior of Poles were also indicated.

\section{Results}

A number of CE assessment approaches have been developed, inventoried and assessed in recent years, for example: Roos Lindgreen et al. (2020, pp. 2-27), Corona et al. (2019), Figge et al. (2018, pp. 297-306), Kirchherr et al. 2017 y., Saidani et al. (2019, pp. 542-559), Kristensen et al. (2020), Kirchherr et al. (2018, pp. 264-272). The large number of existing CE assessment approaches mean that they are often criticized for ignoring research and sector specific factors. Kirchherr et al. (2018, pp. 264-272) believes that the public and private sectors are the key players in the transformation of CE. High initial investment 
costs, time-consuming investment efforts and the need for specialized human resources are cited as some of the most important challenges and barrier to implementing CE practices. Winans et al. (2015, pp. 825-833), Niero et al. (2018, pp. 793-798) and Zarębska (2019) also mention information exchange as an important obstacle to the successful implementation and evaluation of CE. Next are the cultural factors mentioned by Kirchherr et al. (2017) and Sanger (2008) as a CE implementation barrier, especially: reluctance to change, to learn something new, management's emphasis on making decisions, low value of discovering new opportunities and no rewards for innovation.

Many studies on CE have also appeared in Poland, including: Kulczycka (2019), Hausner (2016), Jastrzębska (2017, pp. 229-232), Smol end Kulczycka (2017), Zarębska (2019), PARP (2020). In 2016, on the basis of the order of the Minister of Development, Labor and Technology - the Interministerial Team for the Circular Economy (Międzyresortowy... 2021). Its tasks include: identifying opportunities and threats as well as strengths and weaknesses of the Republic of Poland in the context of the transformation towards $\mathrm{CE}$; developing a position on EU initiatives regarding transformation towards CE development of an action plan for the implementation of CE, specifying in particular the objectives and priorities of action along with their time horizon and the institutions responsible for their implementation. The main goal of this model is to achieve a waste-free economy in which each used commodity is also a secondary raw material with a market value. In 2018, the Ministry of Development also published a document entitled "Roadmap for transformation towards a circular economy" (Mapa drogowa... 2018).

\section{1. Changes in municipal waste management in Poland}

Changes in municipal waste management in Poland are visible especially in the comparison of data from the last several dozen years. There is a trend towards the level of recycling approaching the EU average, but the growth rate is still very slow and variable. Figure 1 presents a comparison of the percentages of municipal waste recycling in the years 1995-2019 in Poland against the background of the EU. According to Eurostat (2021), in the ranking of the average of 28 European countries, there has been an upward trend in recycling of municipal waste for years, amounting to $47.7 \%$ in 2019 (it is uniform, stable). In the case of Poland, an unequal increase in recycling

Polish society towards the implementation of the circular economy and the change of municipal waste management - ecological, economic and social aspect 
is visible, and from 2010 to 2011 a decrease (from 16.3\% to 11.4\%), then a large increase (2013-2015) and in the years 2016-2019 a relatively stable level $(34.8 \%-34.1 \%)$.

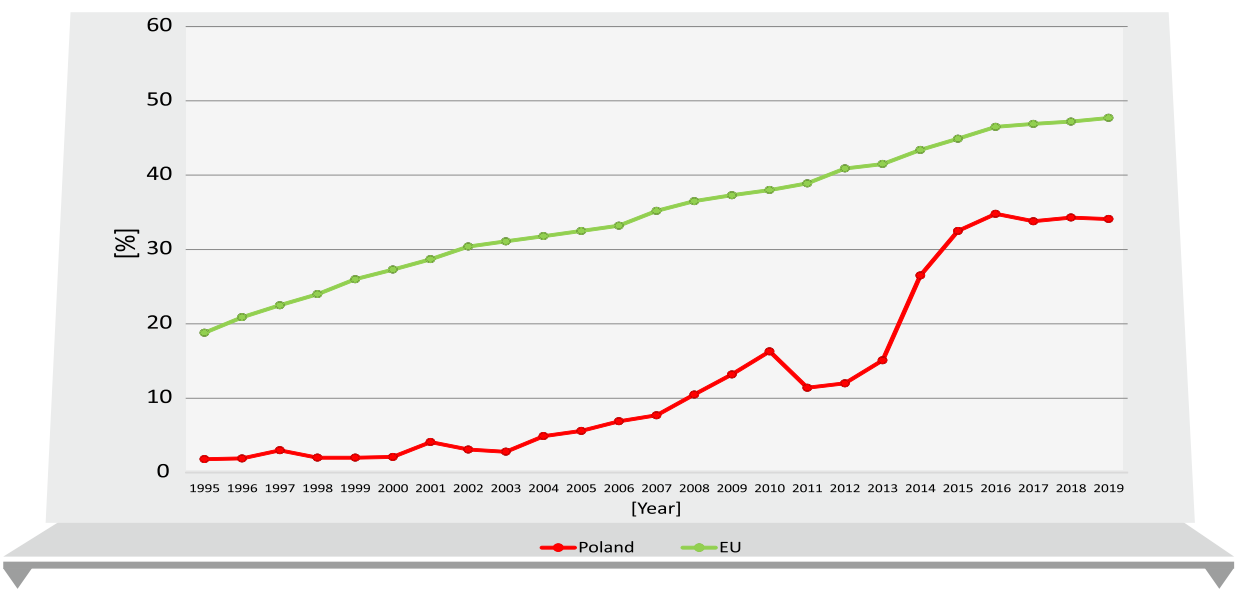

Figure 1. Changes of municipal waste recycling for the period 1995-2019 [\%]

Source: own elaboration based on data from the Eurostat 2021 study

Figure 2 presents the recycling rate of municipal waste in 2019 in selected European countries. According to Eurostat, Poland does not rank well in this ranking, as it is the 9th country below the recycling average (47.7\%), and 19 out of 28 European countries. The Polish recycling rate in 2019 was $34.1 \%$ and was lower than in countries such as: Spain (34.7\%), Hungary (35.9\%), Slovakia $(38.5 \%)$, Norway $(40.9 \%)$, Latvia $(41.0 \%)$, Finland (43.5\%), France $(46.3 \%)$, Sweden (46.6\%). The leaders in the level of recycling of municipal waste in these 28 countries is Germany (66.6\%), 2nd - Slovenia (59.2\%), 3rd - Austria $(58.2 \%)$. Most of these countries have improved their recycling rates by an average of 2-3\% in the last two years (Eurostat 2021). Probably the geographic location and wealth of a given country are of no great importance here, as Poland's neighbors (Germany, Lithuania, Latvia, Slovakia) have better recycling results and their financial situation is different. 
Vol. 25 , No. 2

Germany

Slovenia

Austria

Netherlands

Belgium

Switzerland

Denmark

Italy

Lithuania

Luxembourg

EU (28)

Sweden

France

Finland

Latvia

Norway

Slovakia

Hungary

Spain

Poland

Czechia

Estonia

Croatia

Portugal

Greece

Cyprus

Turkey

Romania

Malta
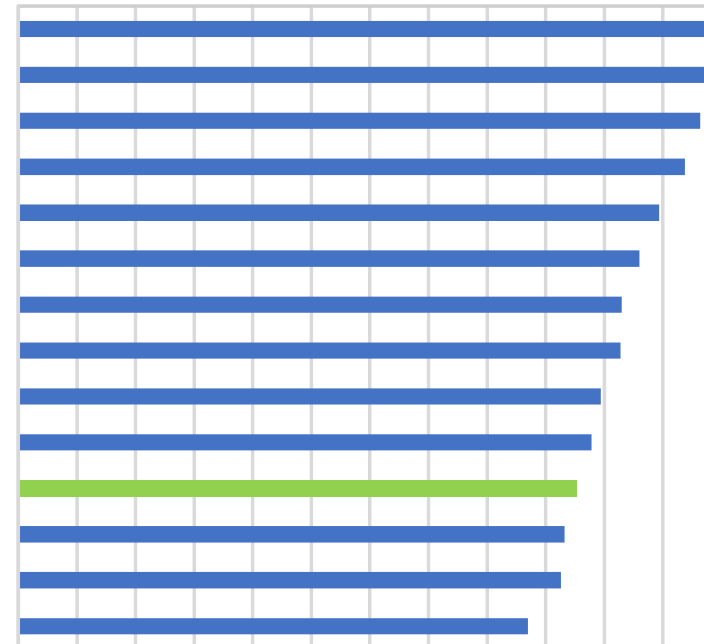

-
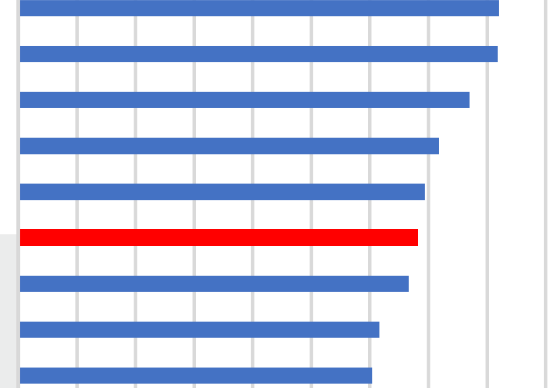

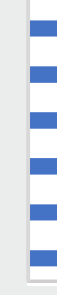

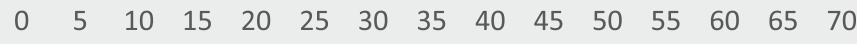

Figure 2. Municipal waste recycling in 2019 by selected Europe countries [\%]

Source: own elaboration based on data from the Eurostat 2021 study

Polish society towards the implementation of the circular economy and the change of municipal waste management - ecological, economic and social aspect 
Despite such a low position of Poland in figure 2 in relation to other European countries, the dynamics of changes is in favor of the national municipal waste management and clearly indicates an increase in recycling (in 1995 - 1.8\%, 1999 - $2.0 \%, 2009-13.2 \%, 2019-34.1 \%)$, and therefore the implementation of the CE concept. These changes are particularly visible in the comparison of the mass of collected municipal waste in Poland subjected to recovery or neutralization in the years 2004-2020 (fig. 3).

According to the CE concept, the country's economy is to function on the principle of closed material cycles, aimed at minimizing the amount of materials and raw materials used in the production process, as well as reducing the amount of waste through rational management of production processes. This applies not only to production and service companies, but also to individuals. We are all customers and our task is to extend the life cycle of products by taking such actions and creating such links within the network of connections/ flow of environmental information, as a result of which waste can once again become a valuable element of the new production process.

As figure 3 shows, in Poland more and more municipal waste is recycled, composted or incinerated with energy recovery, and less and less is landfilled. A visible breakdown of this trend took place in 2016. It was only from 2019 that less municipal waste began to landfill again, and recycling began to increase. This result of waste management is in line with the EU Directives and the general policy in the scope of CE and SD implementation (2008/98/EC; (EU) 2018/851; COM(2011) 571; COM(2014) 398; PARP 2020).

According to the Central Statistical Office (GUS 2020) database, in Poland we generate less municipal and packaging waste each year than in the EU countries. Although the last years of the pandemic indicate a general increase in the mass of municipal waste generated. In 2016, the average European generated $483 \mathrm{~kg}$ of municipal waste, while a Pole - $303 \mathrm{~kg}$ (analogically in 2020: European - approx. $500 \mathrm{~kg}$; Pole - $342 \mathrm{~kg}$ ). According to Eurostat data (2021), this value varies depending on the country from around $280 \mathrm{~kg}$ (in Romania) to as much as $844 \mathrm{~kg}$ per inhabitant (in Denmark). In 2020, 13.1 million Mg (in 2019 - 12.8 million Mg) of municipal waste was collected in Poland (an increase in 2020 by $2.3 \%$ compared to 2019). There was on average $342 \mathrm{~kg}$ of collected municipal waste per one inhabitant, which means an increase by $10 \mathrm{~kg}$ compared to the previous year. Out of 13.1 million $\mathrm{Mg}$ of collected municipal waste, 4.9 million $\mathrm{Mg}$ of waste $(37.4 \%)$ was collected or collected selectively. 


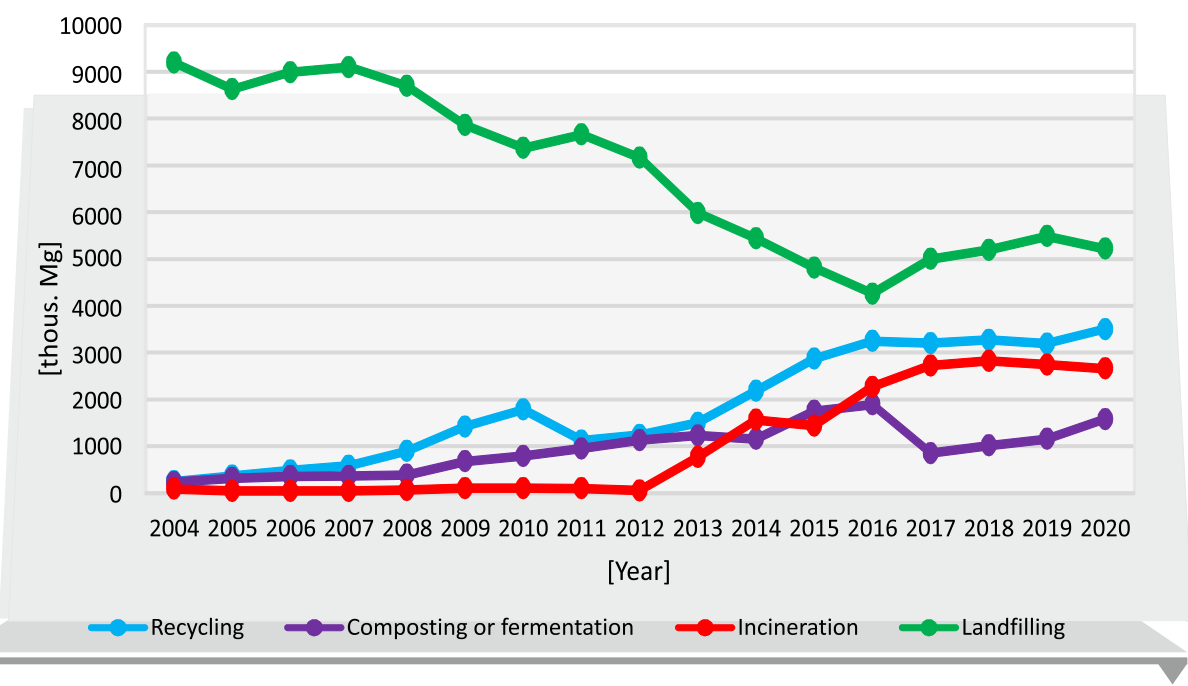

Figure 3. Comparison of statistical data on the weight of collected municipal waste in Poland subjected to recovery or disposal [thous. Mg]

Source: own elaboration based on data from the GUS 2020 study

In 2019, there were 2,190 separate collection points for municipal waste in the country. The municipal waste collection service was provided by 1,352 enterprises. However, Poles still send a lot of municipal waste to the landfill (in 2020 - 5218 thous. Mg), which is considered by Polish and EU legislation as the least desirable way to deal with waste. In four Polish cities, almost $25 \%$ of generated waste is landfilled; the largest number is in the following cities: Łódź (27.6\%), Rzeszów (25.8\%), Kielce (24.3\%) and Zielona Góra (23.8\%). This is a lot considering the fact that by 2035 Poland is to minimize landfilling to $10 \%$. At the end of 2019 , there were 278 municipal waste disposal sites, covering a total area of 1,670 ha. Over $92 \%$ of them were equipped with degassing installations, as a result of which approx. 91153 thousand tons were recovered by burning the captured gas. MJ of thermal energy and approx. 112914 thousand. kWh of electricity. In 2019, 11,371 illegal landfills were liquidated in Poland, of which approx. 26,000 were collected in total. Mg of municipal waste. At the end of 2019, 1,873 illegal landfills were recorded (GUS 2020). 


\section{2. Barriers and ecological challenges}

The Circular Economy System (CE) allows the added value of products to be preserved for as long as possible and the total elimination of waste, thus saving raw materials. It consists in closing the life cycle of products, in which the product does not end up in the bin and in the landfill after its use, but is reused through recovery and recycling. This concept also applies to intraproduction (within the enterprise) and the so-called "Waste exchange" (waste sale/ overproduction/ sale of byproduct to another entrepreneur who can use this commodity for his production). An important element of the above concept is the design of products taking into account environmental aspects (eco-design). In designing, it is assumed that the final product is to have the lowest possible impact on the environment throughout its life cycle and a lower negative effect after its use (design in terms of increasing the efficiency and productivity of products - maintenance, re-use/ multiple use, renewal/ modification, recycling) (Zarębska 2017, pp. 286-295). The above model is presented in figure 4 (Zarębska 2019, p. 271).

Each product has its own environmental impact and most products have a long and complex life cycle. It includes, among others the phase of product design, raw material extraction, product production, packaging, distribution, sale, use, waste generation, collection, repair, recycling and disposal. Therefore, it is advisable to minimize the impact of the product on the environment in all phases of its life cycle, and especially in the phases when this impact is greatest, and to undertake actions in this regard in the most effective way possible. Such an approach should also lead to the reduction of production, use and disposal costs as well as improvement of the competitiveness of enterprises. These aspects are still valid for implementation and therefore the authors of the article place the greatest emphasis on the behavior of individual people, each of whom is a client, but also can be the boss of the enterprise, and each small action in a global perspective has a strong environmental impact. Increasing the recycling of municipal waste in households to $100 \%$ means over 8 million Mg less waste in landfills and at least half of this mass is secondary raw materials for reuse (savings of primary raw materials).

In Poland, there is a very unfavorable phenomenon related to the incineration of waste in domestic furnaces. It concerns especially municipal waste and packaging waste (paper, plastic). This phenomenon is the result of a misunderstanding of the requirements and goals as well as methods of achieving high levels of recovery and recycling in waste management. Such a phenomenon causes air 
pollution near the place of residence, poisoning oneself and neighbors, which contributes to the emergence of respiratory diseases and cancer.

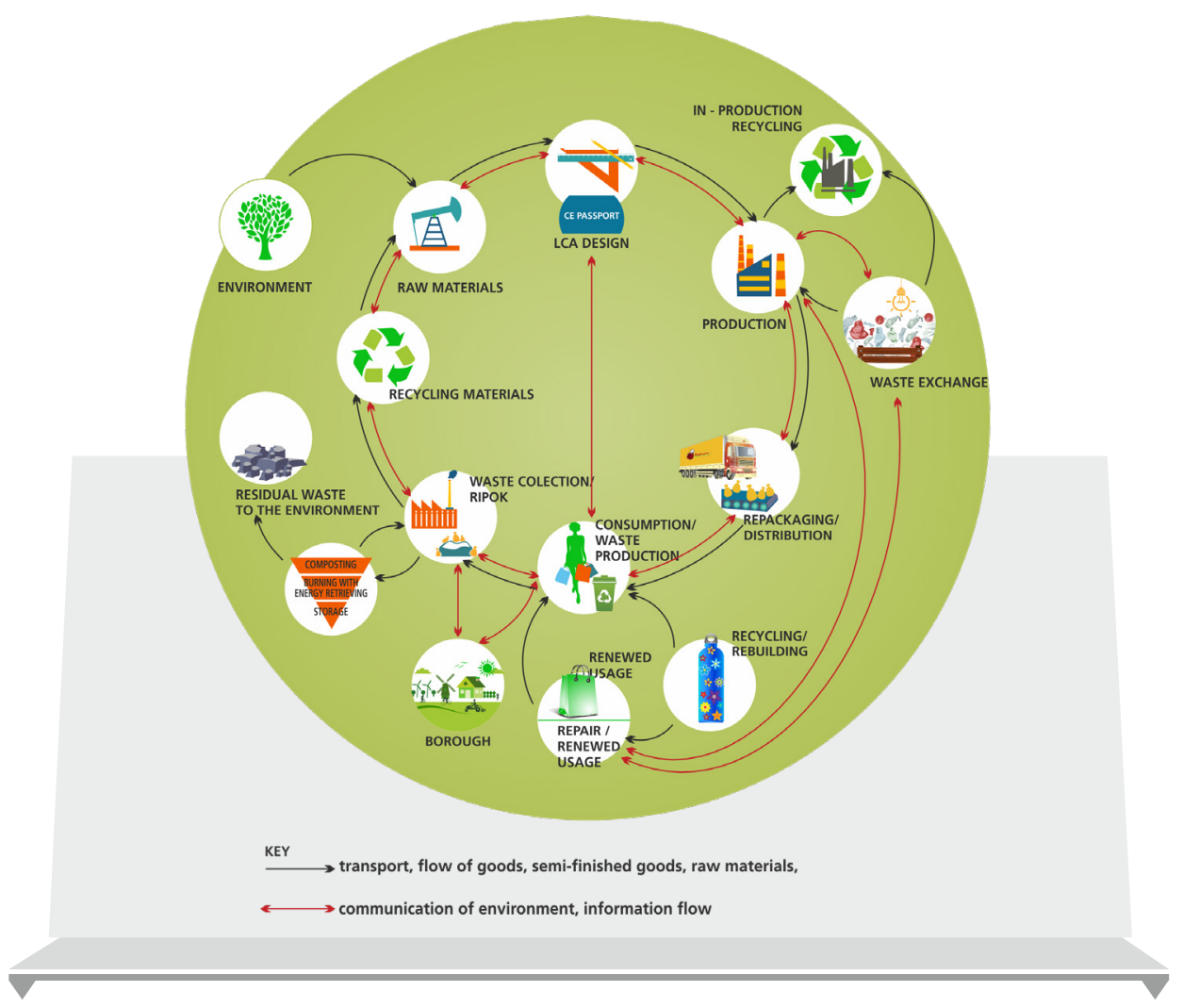

Figure 4. Circular economy model with particular emphasis on the consumption stage and waste management

Source: Zarębska 2019, p. 271

Another, equally dangerous phenomenon that occurs not only in Poland, but it can be safely said that in countries around the world, is fires in landfills and illegal transport of waste from other countries (waste trade). According to the Central Statistical Office (GUS), there were 120 landfill fires in Poland in 2019

Polish society towards the implementation of the circular economy and the change of municipal waste management - ecological, economic and social aspect 
(most often illegal landfills, tire landfills), in which investigations are carried out. The most dangerous of them was the fire of an illegal landfill in Sosnowiec. Not only was the scale of the fire spreading, but most of all the proximity to houses was dangerous.

Many countries also send their waste to Poland to be disposed of in our country against the law. Despite the penalties, the whole procedure is still extremely profitable. Harmful waste products are transported to Poles by Czechs, Norwegians, Italians, French, Swedes and Austria. Hundreds of thousands of tons of rubbish go to us every year, and the cost of their disposal in Gorlice alone amounted to PLN 50 million. Year after year, the situation looks worse and worse (Świat oze.pl 2020).

\subsection{Economic barriers and challenges}

In Poland, CE is defined in the Roadmap for transformation towards a circular economy as a concept in which the value of products, materials and raw materials should remain in circulation for as long as possible and the generation of waste should be minimized as much as possible (Mapa drogowa... 2018).

Table 1 summarizes the prices of some selected goods (blouse, underwear, sweaters, shoes, suit, skirt, pants, dress) in the repair zone, purchase of used goods and new ones at discounters. The authors presented average price ranges in PLN (minimum price - maximum price) of popular goods in large-format stores such as: Tesco, Pepco, TK Maxx, KIK, Auchan, CCC, Deichmann in three Polish cities where the authors work (Poznań, Szczecin and Zielona Góra).

In the case of column 3 - "cheap goods in stores with the so-called "Secondhand", buying directly from people selling used goods, the authors analyzed advertising websites and internet groups (OLX, Facebook), and the prices posted are the minimum and maximum, as the average price of the first ten prices found displayed.

Table 1. Prices of selected goods in the area of repairs, buying used and new goods at discounters

\begin{tabular}{l|c|c|c|c}
\hline \multirow{2}{*}{ Name of product } & REPAIR (PLN) & \multicolumn{3}{|c}{ PURCHASE (PLN) } \\
\cline { 2 - 5 } & $\begin{array}{c}\text { Type of repair and } \\
\text { / or repair price }\end{array}$ & $\begin{array}{c}\text { Cheap goods in } \\
\text { stores with the } \\
\text { so-called "Second } \\
\text { hand", buying } \\
\text { directly from people } \\
\text { selling used goods }\end{array}$ & $\begin{array}{c}\text { New goods in } \\
\text { stores such as: } \\
\text { Tesco, Pepco, } \\
\text { TK Maxx, KIK, } \\
\text { Auchan, CCC, } \\
\text { Deichmann) }\end{array}$ & $\begin{array}{c}\text { New goods } \\
\text { in the } \\
\text { so-called } \\
\text { Chinese" } \\
\text { shops or } \\
\text { bazaars }\end{array}$ \\
\hline Blouse & $10-40$ & $0-60$ & $20-150$ & $20-150$
\end{tabular}




\begin{tabular}{|c|c|c|c|c|}
\hline Underwear & - & $0-30$ & $20-100$ & $10-100$ \\
\hline $\begin{array}{l}\text { Prices of selected } \\
\text { goods in the } \\
\text { area of repairs, } \\
\text { buying used and } \\
\text { new goods at } \\
\text { discounters }\end{array}$ & $\begin{array}{l}\text { Prices of selected } \\
\text { goods in the } \\
\text { area of repairs, } \\
\text { buying used and } \\
\text { new goods at } \\
\text { discounters }\end{array}$ & $20-60$ & $80-150$ & $80-150$ \\
\hline Shoes & $35-150$ & $20-100$ & $69-400$ & $20-150$ \\
\hline Suits & $30-150$ & $50-200$ & Up to 400 & Up to 400 \\
\hline Skirt & $\begin{array}{c}\text { Constriction or fit } \\
\text { 10-55; sewing on } \\
\text { the zipper approx. } \\
15\end{array}$ & $10-50$ & $35-130$ & $20-90$ \\
\hline Trousers & $\begin{array}{c}\text { Zipper sewing } \\
15-25\end{array}$ & $10-30$ & $30-95$ & 20-100 \\
\hline Dress & $10-50$ & $15-100$ & $75-250$ & $20-350$ \\
\hline
\end{tabular}

Source: own study

A comparison of the prices listed in table 1 makes it clear that for buyers there is always an alternative to cheaper clothes or shoes. If the consumer does not have to wear branded clothes, then buying in discount stores, in bazaars or through internet / mobile applications is an alternative to purchasing the goods. From an economic point of view, it is not profitable to repair the goods - it is better to buy a cheaper but new one. This alternative causes used/ damaged clothes or shoes to end up in our household rubbish/ bins. Next, these waste/ used goods are deposited in landfills or incinerated. On the other hand, producers wanting to satisfy customer demand, increase production and new goods are delivered to stores.

Of course, there is a collection of textiles in Poland, but there are few containers and it is not very popular, which means that it is not very effective. Most often, small, unwanted clothes are sold via the Internet, special applications on phones or given to family/ friends.

The key to obtaining high-quality raw material, which will be suitable for further processing, is the selective collection of waste at the stage of their production (i.e. in homes, workplaces, companies, etc.). In the case of municipal waste, such as plastic, glass, metal, paper and cardboard, multi-material packaging, recycling

Polish society towards the implementation of the circular economy and the change of municipal waste management - ecological, economic and social aspect 
in 2019 was $58.7 \%$ (legal requirements - 41\%), and in the EU it was - 66\% (the highest in Belgium - 85.3\%) (Dz. U. 2021 poz. 906, GUS 2020, PARP 2020). Since 2019 , the obligation to segregate waste has been linked to the rubbish fee, which in the case of non-segregated waste is 4 times higher than that of segregated waste. Local governments, which are obliged to organize selective collection, try in various ways to encourage residents and entrepreneurs to properly segregate waste and to make the fees more realistic in relation to the actual amount of waste generated, e.g. by linking the fee to the amount of water used. Probably the increase in prices in recent years for the collection and disposal of mixed waste constituted a great social incentive for recycling.

Motivation for selective waste collection can also be ensured by creating infrastructure that "rewards" for the correct segregation of waste - for example, a network of so-called can be dispensers to which you can return aluminum cans, or as in the case of Biedronka stores, they are Ekomats for plastic packaging. It is an innovative solution in Poland, therefore it occurs sporadically, not in all large cities, not to mention small or medium-sized towns and villages (figure 5). Unfortunately, can machines and Ekomat concern only a selected group of packaging, which does not solve the problem of packaging waste management throughout the country.

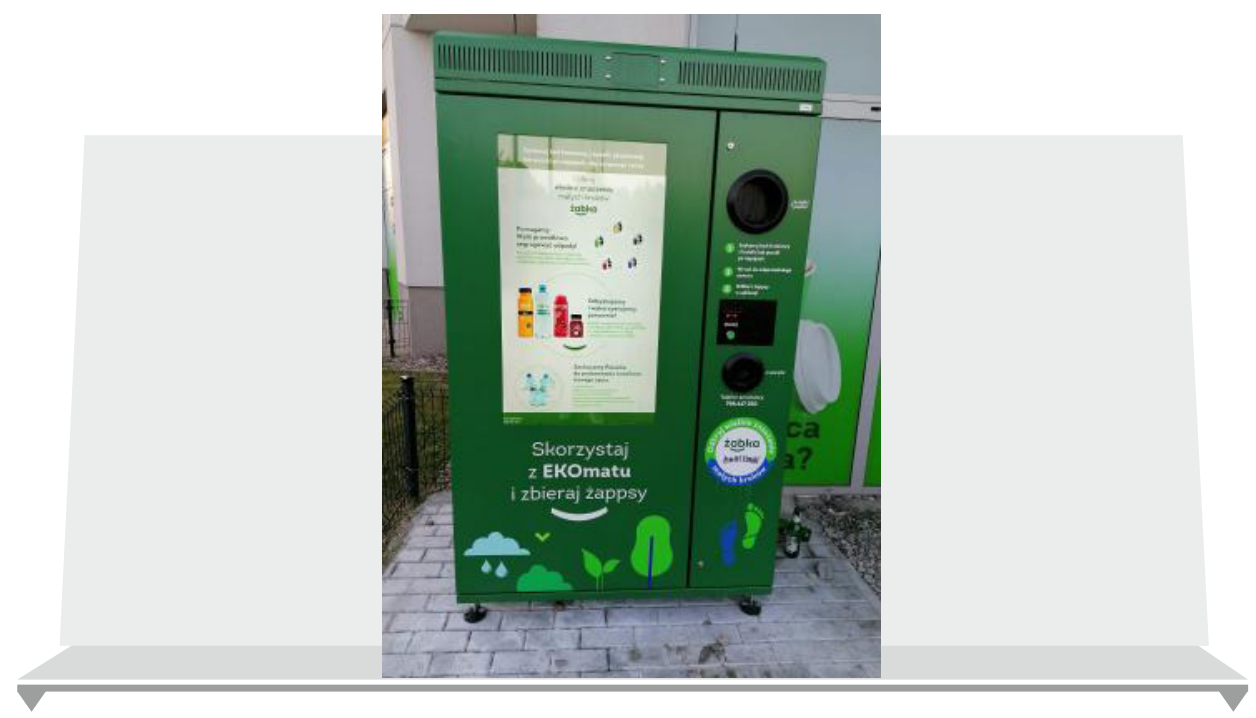

Figure 5. EKOmat of the Biedronka store in Poznań

Source: photo by Joanna Zarebska 


\subsection{Barriers and social challenges}

Ecological awareness, according to one of many definitions, says that it is "understanding the dependence of people on the rest of nature and awareness of the impact that human activity has on the surrounding environment. Awareness means not only an appropriate level of knowledge, but also its rational and emotional assimilation, which causes taking specific actions" (Kobyłko 2007, p. 91). Here, however, it should be noted that knowledge and the related ecological awareness is not enough to take appropriate pro-ecological actions, and concern is also important (Jones and Stafford 2021). An example may be the passive attitude of consumers who know that collecting waste paper is a pro-ecological activity, protecting the natural environment and reducing the demand for primary raw materials, yet do not undertake such activities and are indifferent to them (they show no concern for the environment).

In Poland, there is also a lack of consistency in environmental education, which is not conducive to the acquisition of knowledge and consolidation of pro-ecological attitudes (based on a high level of environmental awareness). Poles learn about the segregation of municipal waste and packaging waste at practically all levels of school education (actually starting from the kindergarten level). Unfortunately, a preschooler or a student, after leaving the classroom for a break in the corridor, in the park for a walk, in the city, in the cinema, in offices, encounters single waste bins that do not preserve the knowledge passed on at school. A similar situation occurs in houses where small kitchens do not contain several containers for segregated waste, or in high-rise buildings, where the proximity of a municipal waste chute does not require segregation. Of course, the described phenomena are not a rule, as there are places in Poland where segregation is more widespread, even "accompanies" the consumer at every step (an example may be, for example: gas stations, railway stations, sometimes largescale commercial facilities, towns using the eco-network of the EKO System AB (System Eko AB, 2015), or eco-innovative enterprises (Zarębska 2019).

Consumer behavior may be balanced, rational, in line with the law and obligations in the field of waste management or seeking to minimize the financial burden, limited to caring for "your own backyard". Such behaviors are described in economics as (Zarębska 2019; Folmer et al. 1996): 1) the herd effect (most do what others do, just like others; if others can do it, so can I), 2) the tragedy of the common pasture (exploitation of the environment as much as possible; use - e.g. forests, public land for municipal waste disposal, 3) NIMBA syndrome (not in my back yard), widespread opposition to certain investments in their immediate

Polish society towards the implementation of the circular economy and the change of municipal waste management - ecological, economic and social aspect 
vicinity, despite recognizing that they are needed at all (e.g. . construction of a waste sorting plant, waste incineration plant). The effects of these abnormal social behavior are detrimental to both the environment/Earth and humans, now and for future generations.

Research conducted in Poland in 2015-2016 by Joanna Zarębska (2019, p. 265) showed that the reason for the still low level of recovery and recycling of waste in homes is: according to $33 \%$ of respondents (respondents) - lack of faith in the proper functioning of the system source segregation; $19.9 \%$ - no containers at the place of residence; $19.1 \%$ - lack of space in the house for several containers; $8.6 \%$ - no appropriate habits in segregating waste; $7 \%$ - no time. As many as $75 \%$ of respondents declared themselves segregating municipal waste, but only $70 \%$ of them segregate waste in all groups (paper and cardboard, metal, plastic, glass, multi-material). The remaining $30 \%$ of the respondents segregate only e.g. paper, plastic or glass, and some only plastic. Unfortunately, 32\% of respondents answered that they sort waste, but sometimes.

The proposals of the surveyed Poles to increase the effectiveness of the selective waste collection system are presented in figure. 6. These include, for example: education of the youngest, purchase of selected waste by large

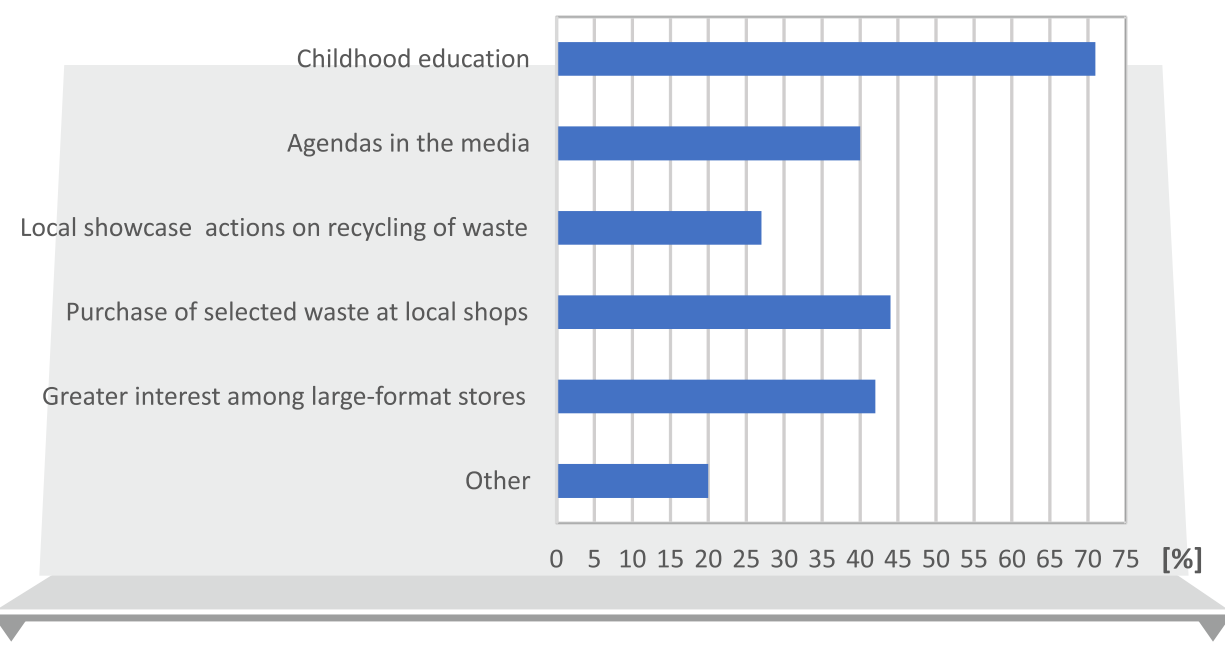

Figure 6. Proposals to increase the effectiveness of the selective collection system for waste

Source: Zarębska 2019, p. 265 
stores (supermarkets) and smaller local stores, information programs in the media, demonstration campaigns for the public on the correct segregation of waste.

In recent years, the so-called Upcycling, which is the process of creative recycling that transforms used products and generated waste into new materials or products of higher quality and value. Upcycling activities are in many cases associated with the independent processing of products and giving them new functionality (e.g. converting EURO wooden pallets into garden furniture). The $\mathrm{CE}$ concept will not be achieved without the support of the "recycling society", so there is still a lot of room for improvement and catching up in the country

\section{Conclusions}

The implementation of the circular economy model requires the cooperation of many entities and the identification of the flow of materials in subsequent stages of the product life cycle, starting from obtaining raw materials, through design, production, consumption, as well as waste collection and management. Cooperation develops dynamically when the market is transparent - the prices and quality of the product / waste are known, there are stable legal solutions, and the client is aware of not only economic but also ecological benefits.

According to the authors of the article, individual consumers have the greatest chance to improve the implementation of CE assumptions. The behavior of individual persons has an impact on waste management. Every little action to improve the state of waste management, repeated by many people from a global perspective, already has a big environmental impact.

Polish society has a general knowledge of the need for recycling, and yet only $75 \%$ of respondents declared waste segregation. In the case of our country, there is no greater "client out". The use of can machines or EKOmats on a larger scale would be one of many incentives and would not force customers to incur costs, e.g. to travel. It seems necessary to introduce more segregated waste containers, especially in large cities with multi-family housing. A detailed description of garbage cans would also be By "going out to the customer".

In addition, enterprises producing goods are of great importance here. Greater transparency, flow of environmental information, eco-design, information for consumers on how to use used parts (upcycling), where to recycle used goods, it would certainly help to increase the level of recycling.

It seems necessary to conduct similar research periodically with public consultations.

Polish society towards the implementation of the circular economy and the change of municipal waste management - ecological, economic and social aspect 


\section{Summary}

Polish society towards the implementation of the circular economy and the change of municipal waste management ecological, economic and social aspect

Circular economy (CE) is seen as a key strategy for achieving sustainable development (SD). One of the components of SD is sustainable production and consumption. Poland, as an EU member state, has for many years been trying to imitate the good practices of other countries in the field of sustainable production and consumption, and above all, in reducing the amount of waste generated. However, the country's economic situation, pandemic, people's mentality, habits and other ecological, economic and social factors mean that the pursuit of $\mathrm{CE}$ is very slow. The aim of the article is to present own research showing the level of recovery and recycling of municipal waste in Poland in comparison to the EU, and the level of preparation of Polish society for the implementation of CE. The survey method with open and closed questions was used in the research. Moreover, the observation of the market and the analysis of the literature on the subject allowed for drawing additional conclusions. Research shows that part of the society does not segregate waste despite the obligation and higher fees, does not believe in CE and, unfortunately, disposes of waste incorrectly. In addition, the differences between the repair/ refurbishment and the purchase of goods from discount stores, or second-hand goods are so slight that it is not profitable for the consumer to repair, regenerate used goods - from an economic point of view, it is better to buy a new one at " cheap "shop.

Keywords: circular economy; waste management; concern for the environment; development barriers.

\section{Streszczenie}

Polskie społeczeństwo wobec wdrażania gospodarki o obiegu zamkniętym i zmianie gospodarki odpadami komunalnymi aspekt ekologiczny, ekonomiczny i społeczny

Gospodarka o obiegu zamkniętym (CE) jest postrzegana jako kluczowa strategia osiągnięcia zrównoważonego rozwoju (SD). Jedną ze składowych SD jest zrównoważona produkcja 
i konsumpcja. Polska jako kraj członkowski UE od wielu lat stara się naśladować dobre praktyki innych krajów w zakresie zrównoważonej produkcji i konsumpcji, a przede wszystkim zmniejszenia ilości wytwarzanych odpadów. Jednak sytuacja gospodarcza kraju, pandemia, mentalność ludzi, przyzwyczajenia i inne czynniki ekologiczne, ekonomiczne i społeczne powodują, że dążenie do CE następuje bardzo powoli. Celem artykułu jest zaprezentowanie badań własnych ukazujących poziom odzysku i recyklingu odpadów komunalnych $w$ Polsce na tle UE, oraz stopień przygotowania polskiego społeczeństwa do wdrożenia CE. W badaniu wykorzystano metodę ankietową z pytaniami zamkniętymi i otwartymi. Ponadto obserwacja rynku i analiza literatury przedmiotu pozwoliły na wyciągniecie dodatkowych wniosków. $Z$ badań wynika, że część społeczeństwa nie segreguje odpadów pomimo obowiązku i większych opłat, nie wierzy w CE i niestety pozbywa się odpadów w sposób nieprawidłowy. Ponadto różnice pomiędzy naprawą/odnowieniem a zakupem towarów ze sklepów dyskontowych, lub towarów z "drugiej ręki" są tak niewielkie, że konsumentowi nie opłaca się naprawiać, regenerować zużytych towarów - z ekonomicznego punktu widzenia lepiej kupić nowy w "tanim" sklepie.

\section{Słowa}

kluczowe: gospodarka o obiegu zamkniętym, gospodarowanie odpadami, troska o środowisko, bariery rozwojowe.

JEL Classification: Q01, Q53.

\section{References}

$\operatorname{COM}(2011) 571$ final, 2011. Roadmap to a Resource Efficient Europe, Communication from the Commission to the European Parliament, the Council, the European Economic and Social Committee and the Committee of the Regions, European Commission, Brussels.

$\operatorname{COM}(2014) 398$ final of 02.07.2014. Towards a circular economy: A zero waste programme for Europe. Communication from the Commission to the European Parliament, the Council, the European Economic and Social Committee and the Committee of the Regions. Brussels.

Corona, B.; Shen, L.; Reike, D.; Rosales Carreón, J. and Worrell, E. (2019), Towards sustainable development through the circular

Polish society towards the implementation of the circular economy and the change of municipal waste management - ecological, economic and social aspect 
economy - A review and critical assessment on current circularity metrics. Resources, Conservation and Recycling, Vol. 151, pp. 1-15, DOI: 10.1016/j. rescon-rec.2019.104498.

Directive 2008/98/EC of the European Parliament and of the Council of 19 November 2008 on waste and repealing certain Directives, Official Journal of the European Union L 312/pp. 3-12.

Directive (EU) 2018/851 of the European Parliament and of the Council of 30 May 2018 amending Directive 2008/98/EC on waste, 2018, Official Journal of the European Union L 150, 14.6.2018, pp. 109-140. Brussels.

EEA (2021). Waste generation and decoupling in Europe. Available online: https://www.eea.europa.eu/data-and-maps/indicators/wastegeneration-5/assessment (28 June 2021 - access date).

Eionet Report (2019) - ETC/WMGE 2019/4 - Poland. Resource efficiency and circular economy in Europe - even more from less. An overview of policies, approaches and targets of Poland in 2018. Available online: https://www.eionet.europa.eu/etcs/etc-wmge/products/countryfactsheets-on-resource-efficiency-and-circular-economy-in-europe (28 June 2021 - access date).

Ellen MacArthur Foundation (2016). Intelligent Assets: Unlocking the Circular Economy Potential. Available online: https://www. ellenmacarthurfoundation.org/assets / downloads / publications / EllenMacArthurFoundation_Intelligent_Assets_080216.pdf (10 June 2021 - access date).

Eurostat 2021, Official Website. Available online: https://ec.europa.eu/ eurostat/databrowser/view/ t2020_rt120/default/table?lang=en (20 June 2021 - access date).

Figge, F.; Thorpe, A. S.; Givry, P.; Canning, L. and Franklin-Johnson, E. (2018). Longevity and Circularity as Indicators of Eco-Efficient Resource Use in the Circular Economy. Ecological Economics Vol. 150, pp. 297-306, 10.1016/j.ecolecon.2018.04.030.

Folmer, H.; Gabel, L. and Opschor, H. (1996). Ekonomia środowiska i zasobów naturalnych, Publisher: Krupski i S-ka: Warszawa. Poland, p. 471. (in Polish).

GUS (2020). Ochrona środowiska, (in Polish). Available online: https:// stat.gov.pl/obszary-tematyczne/srodowisko-energia/srodowisko/ ochrona-srodowiska-2020,1,21.html (2 Juli 2021- access date).

Hausner, J. (2016). Przyszłość gospodarki rynkowej - od oportunistycznej do relacyjnej gry ekonomicznej, Open Eyes Book, Open Eyes Economy Summit, Kraków (in Polish). Available online: https://www.pibr.org.pl/ static/items/publishing/ OPEN_EYES_BOOK_2017_PL.pdf (9 Juli 2021 access date).

Jastrzębska, E. (2017). Gospodarka o obiegu zamkniętym - nowa idea czy stare 
podejście? Dobre praktyki społecznie odpowiedzialnych przedsiębiorstw, Prace Naukowe Uniwersytetu Ekonomicznego we Wrocławiu, No 491, pp. 229232. (in Polish). DOI: 10.15611/pn.2017.491.21.

Jones, E.-A. and Stafford, R. (2021). Neoliberalism and the Environment: Are We Aware of Appropriate Action to Save the Planet and Do We Think We Are Doing Enough? Earth 2(2), pp. 331-339. https:/ / doi.org/10.3390/ earth2020019 (20 June 2021 - access date).

Kirchherr, J.; Piscicelli, L.; Bour, R.; Kostense-Smit, E.; Muller, J.; Huibrechtse-Truijens, A. and Hekkert, M. (2018). Barriers to the Circular Economy: Evidence from the European Union (EU), Ecological Economics Vol. 150, pp. 264-272, 10.1016/j.ecolecon.2018.04.028.

Kirchherr, J.; Reike, D. and Hekkert, M. (2017). Conceptualizing the circular economy: An analysis of 114 definitions, Resour. Conserv. Recycl. Vol. 127, 10.1016/j.resconrec.2017.09.005.

Kristensen, H. S.; Mosgaard, M. A.; Remmen, A. (2020). Circular public procurement practices in Danish municipalities, J. Cleaner Prod., Vol. 281, 10.1016/j.jclepro.2020.124962.

Kobyłko, G. (ed.), (2007). Pro-ecological enterprise management, Publisher: Akademia Ekonomiczna we Wrocławiu, Wrocław (in Polish).

Korhonen, J.; Nuur, C.; Feldmann, A. and Birkie, S. E. (2018). Circular economy as an essentially contested concept, J. Cleaner Prod. Vol. 175, pp. 544-552, DOI: 10.1016/j.jclepro.2017.12.111.

Kulczycka, J. (2019). Circular economy in politics and research. Publisher: Instytut Gospodarki Surowcami Mineralnymi i Energią PAN, Kraków (in Polish).

Mapa drogowa transformacji w kierunku gospodarki o obiegu zamkniętym (2018). Konspekt do prac Zespołu do spraw Gospodarki o Obiegu Zamkniętym. Ministerstwo Rozwoju. (in Polish). Available online: https:/ / miir.bip.gov. $\mathrm{pl} /$ projekty-zarzadzen-uchwal-i-obwieszczen/projekt-mapy-drogowejtransformacji-w-kierunku-goz.html (2 Juli 2021 - access date).

Matschewsky, J. (2019). Unintended circularity? - Assessing a productservice system for its potential contribution to a circular economy, Sustainability 11(10), DOI: 10.3390/su11102725.

Międzyresortowy Zespół ds. Gospodarki o Obiegu Zamkniętym, Minister Rozwoju, Pracy i Technologii. Available online: https://www.gov. pl/web/rozwoj-praca-technologia/zespol-ds-gospodarki-o-obieguzamknietym (2 Juli 2021 - access date).

Niero, M. and Rivera, X. C. S. (2018). The Role of Life Cycle Sustainability Assessment in the Implementation of Circular Economy Principles in Organizations, Procedia CIRP. 69, pp.793-798, 10.1016/j.procir.2017.11.022. PARP (2020). Ocena zapotrzebowania na wsparcie przedsiębiorstw w zakresie gospodarki o obiegu zamkniętym (circular economy). Raport końcowy. Publisher:

Polish society towards the implementation of the circular economy and the change of municipal waste management - ecological, economic and social aspect 
Polska Agencja Rozwoju Przedsiębiorczości. Warszawa 2020 (in Polish). Available online: https://www.parp.gov.pl/component/publications/ publication/ocena-zapotrzebowania-na-wsparcie-przedsiebiorstw-wzakresie-gospodarki-o-obiegu-zamknietym-circular-economy (2 Juli 2021 - access date).

Pożary odpadów (2021), (in Polish) Available online: https:// portalkomunalny.pl/gospodarka-odpadami/ pozary-skladowiskaodpady/ (07 June 2021 - access date).

Roos Lindgreen, E.; Salomone, R. and Reyes, T. (2020). A critical review of academic approaches, methods and tools to assess circular economy at the micro level. Sustainability 12(12), pp. 2-27, 10.3390/su12124973

Rozporządzenie Ministra Klimatu i Środowiska z dnia 10 maja 2021 r. w sprawie sposobu selektywnego zbierania wybranych frakcji odpadów (Dz. U. 2021 poz. 906) (in Polish).

Saidani, M.; Yannou, B.; Leroy, Y.; Cluzel, F. and Kendall, A. (2019). A taxonomy of circular economy indicators, J. Cleaner Production 207, pp. 542-559, 10.1016/j.jclepro.2018.10.014. 587

Sanger, M. B. (2008). From measurement to management: Breaking through the barriers to state and local performance, Public Administration Review Vol. 68, 10.1111/j.1540-6210.2008.00980.x.

Smol, M., Kulczycka, J. and Avdiushchenko, A. (2017). Circular economy indicators in relation to ecoinnovation in European regions. Clean Technol. and Environm. Policy 19(3).

System Eko AB, (2015), Available online: http:/ /www.otzo.most.org.pl/ zwe/System_Eko_AB_Plock_2015.pdf (2 Juli 2021 - access date).

Świat oze.pl (2020). Ochrona środowiska. Problemy z odpadami w 2020 roku - przeglad. (in Polish). Available online: https://swiatoze.pl/problemy-zodpadami-w-2020-roku-przeglad/ (2 Juli 2021 - access date).

Ustawa z dnia 13 września 1996 r. o utrzymaniu czystości i porządku w gminach (t.j. Dz. U. 2021, poz. 888) (in Polish) Available online: http:// isap.sejm.gov.pl/isap.nsf/DocDetails.xsp?id=WDU19961320622 (10 June 2021 - access date).

Ustawa z dnia 14 grudnia 2012 r. o odpadach (t.j. Dz. U. 2021, poz. 779, 784) (in Polish) Available online: https://isap.sejm.gov.pl/isap.nsf/ DocDetails.xsp?id=WDU20130000021 (10 June 2021- access date).

Winans, K.; Kendall, A.; Deng, H. (2015). The history and current applications of the circular economy concept, Renew. Sustain. Energy Rev. Vol. 68, pp. 825-833, 10.1016/j.rser.2016.09.123

Zarębska, J. (2017). Gospodarka o obiegu zamkniętym drogą do zrównoważonego rozwoju, Systemy Wspomagania w Inżynierii Produkcji Vol. 6, iss. 7, pp. 286-295 (in Polish). Available online: http://yadda.icm. edu.pl/yadda/element/bwmeta1.element.baztech-2f642db5-beb0-4e45- 
9350-66681cc98e33 (20 June 2021 - access date).

Zarębska, J., Żabińska, I., Cierna, H. and Sujova, E. (2018). Assessment of the changes in the economy of municipal waste in Poland after 2004, [in:] Human Safety in Work Environment, Operating Machinery and Equipment, Integrated Management Systems: Quality - Environment Safety - Technology: Proceedings of the International Conference, Gdańsk, Polska. STE Group Sp. z o. o. - New Trends in Production Engineering, Warszawa, Vol. 1, iss. 1, pp. 55-61. DOI: 10.2478/ntpe-2018-0007.

Zarębska, J. (2019). Packaging waste management in the context of a circular economy - the essence, tools, environmental communication. Publisher: University of Zielona Góra: Zielona Góra. (in Polish).

Zarębska, J. and Lewicka, B. (2020). Changes in the waste packaging management and implementation for circular economy - polish case study, Acta Innovations No 34, pp. 50-57. DOI: 10.32933/ ActaInnovations.34.5.

Polish society towards the implementation of the circular economy and the change of municipal waste management - ecological, economic and social aspect 